\title{
Role of gypsum and compost in reclaiming saline-sodic soils
}

\author{
Mohamed K. Abdel-Fattah \\ Soil Science Department, Faculty of Agriculture, Zagazig University, Egypt
}

\begin{abstract}
A leaching experiment using columns technique was carried out to evaluate the efficiency of gypsum, water hyacinth compost "WHC", rice straw compost "RSC" and their different combinations on reclamation of clay saline-sodic soils. Soils were collected from Sahl El-Hossinia, El-Sharkia Governorate, Egypt. The results of the study indicated that all the used amendments either, singly or in combination showed a pronounced decreased in EC, pH, SAR, and ESP compared with control. The results showed that combined treatments more efficient than single one. Increase the rate of gypsum used leads to an increase in decrease salinity as well as sodicity. Concerning WHC and RSC, Results showed that, RSC showed a relatively greater effect on reducing EC, $p H$, SAR and ESP compared with WHC. The studied treatments could be arranged in the following order, $100 \% \mathrm{GR}+20 \mathrm{Mgfed}^{-1} \mathrm{RSC}>100 \% \mathrm{GR}+20 \mathrm{Mgfed}^{-1} \mathrm{WHC}>50 \% \mathrm{GR}+10 \mathrm{Mgfed}^{-1} \mathrm{RSC}>$ $50 \% \mathrm{GR}+10 \mathrm{Mgfed}^{-1} \mathrm{WHC}>100 \% \mathrm{GR}>\mathrm{RSC}>\mathrm{WHC}>$ control. This study suggests that application of gypsum combined with WHC or RSC enhanced reclamation and caused more decreases in salinity as well as sodicity.
\end{abstract}

Keywords: saline, sodic, Soil, gypsum, water hyacinth, rice straw, compost

\section{Introduction}

Soil degradation caused by salinization and sodification is of universal concern. Food and Agriculture Organization (FAO) of the United Nations reported that nearly one billion hectares of soil around the world were having some degree of salinization and sodification problem [1]. In Egypt, improving salt affected soils is considered as an important part in the agricultural security program. Gypsum is commonly used for the reclamation of saline-sodic and sodic soils. Gypsum [2] and organic matter [3] are some of the amendments which have been used. Gypsum is the most commonly used amendment for sodic soil reclamation and for reducing the harmful effects of high sodium irrigation water sin agricultural areas because of its solubility, lowcost, availability and ease of handling [2]. Studies on the effect of gypsum application on saline-sodic soil reclamation have shown that the soil receiving gypsum at higher rate removes the greatest amount of $\mathrm{Na}^{+}$from the soil columns and causes a substantial decrease in soil electrical conductivity (EC) and sodium adsorption ration (SAR) [4].

It has been proved that some organic sources can be applied to reclaim salt and sodic affected soils. The addition of organic matter in conjunction with gypsum has been successful in reducing adverse soil properties associated with sodic soils. Addition of organic matter and gypsum to the surface soil will decrease spontaneous dispersion and EC down to the subsoil, compared to the addition of gypsum alone [5].

The modern concept of environmental management is based on the recycling of waste and composting is a safe form of treatment of some waste and the reclamation of the nutrients contained in them [6]. Compost is an organic matter resource resulted from exploiting wastes through the controlled bioconversion process. It seems to meet the objectives of alternative agriculture system and the growing consensus of both environmentalists and those concerned with the public health through solving the waste disposal problem and its application in sustainable agriculture instead of ecologically undesirable mineral fertilization. Numerous studies have already shown the benefits of organic amendments in improving physical, chemical and biological properties of soil that depending on the amount and composition. Although, these parameters change slowly and several years are necessary to obtain significant differences, biological and biochemical parameters are more sensitive and can provide earlier measurements of changes produced by soil management ([7], [8], [9], [10] and [11]).

Physical properties like bulk density, porosity, void ratio, water permeability and hydraulic conductivity were significantly improved when FYM $\left(10 \mathrm{t} \mathrm{ha}^{-1}\right)$ was applied in combination with chemical amendments resulting enhanced rice and wheat yields in sodic soil [12]. Other organic materials like rice straw, wheat straw, rice husk and chopped salt grass also improved these physical properties of a saline sodic soil. The tillering, plant height, biomass and paddy yield were significantly increased [13]. Soil organic matter encourages granulation, increases cation exchange capacity (CEC) and is responsible for up to $90 \%$ adsorbing power of the soils. Cations such as $\mathrm{Ca}^{2+}, \mathrm{Mg}^{2+}$ and $\mathrm{K}^{+}$are produced during decomposition [14]. The main objective of this investigation was study effect of gypsum, compost (i.e. WHC and RSC) and their combinations on reclaiming saline-sodic soils in Egypt. 


\subsection{Soil sampling}

\section{Materials And Methods}

Soil samples were collected from Sahl El-Hossinia, El-Sharkia Governorate, Egypt. They were air dried, crushed and sieved through a 2-mm sieve and analyzed for their physicochemical properties (Table 1).

Table 1. Physical and chemical properties of studied soil

\begin{tabular}{|c|c|}
\hline \multirow{2}{*}{\multicolumn{2}{|c|}{$\begin{array}{l}\text { Property } \\
\text { Particle size distribution [\%]: }\end{array}$}} \\
\hline & \\
\hline - Clay & 42.1 \\
\hline - Silt & 26.6 \\
\hline - Sand & 31.3 \\
\hline - Texture class & Clay \\
\hline \multicolumn{2}{|l|}{ Soil moisture characteristics [\%]: } \\
\hline - Saturation percent & 67.5 \\
\hline - Field capacity & 33.8 \\
\hline - Wilting point & 16.9 \\
\hline \multicolumn{2}{|l|}{ Density [Mg.m $\left.{ }^{-3}\right]$ : } \\
\hline - Bulk density & 1.43 \\
\hline - Total porosity [\%] & 46.0 \\
\hline Organic matter $\left[\mathrm{g} \mathrm{kg}^{-1}\right]$ & 5.2 \\
\hline $\mathrm{CaCO}_{3}\left[\mathrm{~g} \mathrm{~kg}^{-1}\right]$ & 98.0 \\
\hline \multicolumn{2}{|l|}{ Soluble ions, EC and pH: } \\
\hline - EC $\left(\mathrm{dSm}^{-1}\right)$ [Soil paste extract] & 20.34 \\
\hline - $\mathrm{pH}$ [Soil suspension 1:2.5] & 8.36 \\
\hline \multicolumn{2}{|l|}{ - Soluble ions $\left(\mathrm{mmol}_{\mathrm{c}} \mathrm{L}^{-1}\right)$} \\
\hline - $\mathrm{Na}^{+}$ & 191.86 \\
\hline - $\mathrm{K}^{+}$ & 3.67 \\
\hline - $\mathrm{Ca}^{2+}$ & 16.94 \\
\hline - $\mathrm{Mg}^{2+}$ & 21.25 \\
\hline - $\mathrm{Cl}^{-}$ & 164.46 \\
\hline - $\mathrm{HCO}_{3}^{-}$ & 10.35 \\
\hline - $\mathrm{SO}_{4}=$ & 58.91 \\
\hline - SAR & 43.91 \\
\hline \multicolumn{2}{|c|}{ Exchangeable cations, CEC and ESP } \\
\hline $\mathrm{Na}^{+}$ & 12.81 \\
\hline - $\quad \mathrm{K}^{+}$ & 3.25 \\
\hline - $\mathrm{Ca}^{2+}$ & 6.19 \\
\hline - $\mathrm{Mg}^{2+}$ & 10.14 \\
\hline - $\quad$ CEC $\left(\mathrm{cmol}_{\mathrm{c}} \mathrm{kg}^{-1}\right)$ & 32.39 \\
\hline - ESP & 39.55 \\
\hline
\end{tabular}

\subsection{Experimental setup}

Eight groups of 24 soil cores $(30-\mathrm{cm})$ each were treated with one of the following treatments (Table 2). Polyvinyl chloride (PVC) cylindroids tubes of $40-\mathrm{cm}$ height and $16-\mathrm{cm}$ inside diameter were used for this purpose. All amendments were mixed with whole soil matrix $(30-\mathrm{cm})$.

Table 2. Detail of different treatments

\begin{tabular}{cccc}
\hline Treatments & $\begin{array}{c}\text { Gypsum } \\
\text { [as percent of GR] }\end{array}$ & $\begin{array}{c}\text { WHC* } \\
{\left[\mathrm{Mg.fed}^{-1}\right]}\end{array}$ & $\begin{array}{c}\text { RSC** } \\
{\left[\mathrm{Mg.fed}^{-1}\right]}\end{array}$ \\
\hline T1 & 0.0 & 0.0 & 0.0 \\
T2 & 100 & 0.0 & 0.0 \\
T3 & 0.0 & 20.0 & 0.0 \\
T4 & 0.0 & 0.0 & 20.0 \\
T5 & 100 & 20.0 & 0.0 \\
T6 & 100 & 0.0 & 20.0 \\
T7 & 50.0 & 10.0 & 0.0 \\
T8 & 50.0 & 0.0 & 10.0 \\
\hline *Water hyacinth compost and ** Rice straw compost & &
\end{tabular}

\subsection{Calculation of amendments}

The soil amendments used in this experiment were, gypsum, water hyacinth compost "WHC", rice straw compost "RSC". Gypsum requirements (GR) were calculated to reduce the initial ESP from 39.55 to $10 \%$ for 30-cm soil matrix according to [15]. The gypsum was of $97 \%$ purity and its addition rate was $16.97 \mathrm{Mgfed}^{-1}$.

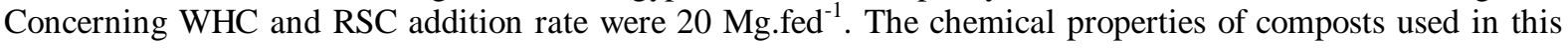
experiment are presented in Table 3. 


\begin{tabular}{|c|c|c|}
\hline Property & WHC* & RSC* \\
\hline $\mathrm{EC}\left[\mathrm{dS} \cdot \mathrm{m}^{-1}\right]$ & 2.86 & 2.35 \\
\hline $\mathrm{pH}$ [Soil suspension 1.5] & 7.66 & 7.21 \\
\hline $\mathrm{N}[\%]$ & 1.85 & 1.78 \\
\hline $\mathrm{P}[\%]$ & 0.56 & 0.53 \\
\hline $\mathrm{K}[\%]$ & 2.73 & 2.46 \\
\hline $\mathrm{Fe}\left[\mathrm{mg} \cdot \mathrm{kg}^{-1}\right]$ & 2.99 & 1.63 \\
\hline $\mathrm{Mn}\left[\mathrm{mg} \cdot \mathrm{kg}^{-1}\right]$ & 890.5 & 476 \\
\hline $\mathrm{Zn}\left[\mathrm{mg} \cdot \mathrm{kg}^{-1}\right]$ & 88.95 & 99.15 \\
\hline $\mathrm{Cu}\left[\mathrm{mg} \cdot \mathrm{kg}^{-1}\right]$ & 45.82 & 51.43 \\
\hline Organic carbon $\left[\mathrm{g} \cdot \mathrm{kg}^{-1}\right]$ & 323.8 & 351.1 \\
\hline Organic matter $\left[\mathrm{g} \cdot \mathrm{kg}^{-1}\right]$ & 558.2 & 605.3 \\
\hline $\mathrm{C} / \mathrm{N}$ ratio & 17.5 & 19.72 \\
\hline
\end{tabular}

\subsection{Leaching process}

After mixing amendments with soil matrix, the soils were leached with water having EC $1.2 \mathrm{dSm}^{-1}$. Leaching was done using intermittent method so as to add portions to the already saturated soil columns; and obtain leachates equal to the added portions. Reclamation requirements (RR) were calculated to reduce the initial $\mathrm{EC}_{\mathrm{e}}$ from 20.34 to $4.0 \mathrm{dSm}^{-1}$ for $30-\mathrm{cm}$ soil matrix according to Reeve equation [16]. The equation is as follows:

$$
\frac{\mathrm{D}_{\mathrm{iw}}}{\mathrm{D}_{\mathrm{s}}}=\frac{\mathrm{EC}_{\mathrm{ei}}}{5 \times \mathrm{EC}_{\mathrm{ef}}}+0.15 \quad \text { Eq. (1) }
$$

Where $\mathrm{D}_{\mathrm{iw}}$ is the depth of leaching water $(\mathrm{cm})$, Ds is the depth of soil $(\mathrm{cm}), \mathrm{EC}_{\mathrm{ei}}$ is the soil salinity $\left(\mathrm{dSm}^{-1}\right)$ before leaching and $\mathrm{EC}_{\mathrm{ef}}$ is the soil salinity $\left(\mathrm{dSm}^{-1}\right)$ after leaching. Calculated $\mathrm{D}_{\mathrm{iw}}$ (equal to $35-\mathrm{cm}$ ) was divided into 7 leachates; each one was $5-\mathrm{cm}(1005-\mathrm{ml}$ of water leaching). Leachates were collected and analyzed for salinity.

\subsection{Methods used for analysis}

Following termination of leaching, each soil columns were separated into 3 segments as follows: $0-10$, 10-20 and 20-30 cm. Soil of each segment was air dried, crushed, sieved through a 2-mm sieve and analysis according to the methods described by U.S., Salinity Laboratory Staff [15].

\subsection{Calculations and statistical analysis}

\subsubsection{Gypsum requirements (GR)}

Gypsum requirements (GR) were calculated to reduce the initial ESP from 39.55 to $10 \%$ for $30-\mathrm{cm}$ soil matrix as follows.

$$
G R=\frac{E S P_{i}-E S P_{f}}{100} \times C E C \times 1.72 \quad \text { Eq. (2) }
$$

Where GR: gypsum requirement $\left(\mathrm{Mgfed}^{-1}\right), \mathrm{ESP}_{\mathrm{i}}$ : actual ESP of the soil, $\mathrm{ESP}_{\mathrm{f}}$ : ESP required to be reached by reclamation and CEC: cation exchange capacity $\left(\mathrm{cmol}_{\mathrm{c}} \mathrm{kg}^{-1}\right)$.

\subsubsection{Sodium adsorption ratio (SAR)}

Sodium adsorption ratio (SAR) was estimated by using the following equation where ionic concentration of the saturation extracts are expressed in $\mathrm{mmol}_{\mathrm{c}} \mathrm{L}^{-1}$

$$
S A R=\frac{N a^{+}}{\sqrt{\frac{C a^{2+}+M g^{2+}}{2}}} \quad \text { Eq. (3) }
$$

\subsubsection{Exchangeable sodium percentage (ESP)}

Exchangeable sodium percentage (ESP) was estimated by using the following equation

$$
E S P=\frac{100(-0.0126+0.01475 S A R)}{1+(-0.0126+0.01475 S A R)} \quad \text { Eq. (4) }
$$

\subsubsection{Statistical analysis}

Data were analyzed using MSTAT-C version 2.1 developed by Russel [17]. 


\section{Results And Discussion}

Results indicate that all the used amendments either, singly or in combination showed a pronounced decreased in soil salinity indicators (EC, pH, SAR and ESP) at the end of leaching process. Nearly all indicators showed a gradually increase with the depth of soil. This indicates that the surface soil section lost more soluble salts than subsurface ones. The only exception is exchangeable calcium, which showed an opposite trend. Increased salinity with soil depth is in agreement with the findings of [18], who reported that some of the leached salts from surface layers accumulate in the subsurface ones due to leaching. Reclamation amendments enhanced the exchangeable calcium. Generally, the optimum combination for decreasing $\mathrm{pH}$, EC, soil sodicity and increasing salt removal was obtained by the treatment of $\mathrm{T}_{6}$.

\subsection{Salt removal}

The changes in the EC of leachate during leaching of the untreated and treated saline-sodic soil are shown in Fig. 1. Generally, results show that a very sharp decreased in EC values for all treatments, particularly at the beginning period of leaching process. Soluble salts removed in leachates depended on the number of leaching carried out. A sharp decreased in occurred at the beginning period of leaching process; greater portions of salts were removed in the first two or three collections of leachates. Also, the lower EC values were found in untreated soil (control), particularly at the beginning of the leaching process. Concerning the effect of different amendments on salt leaching, data illustrated in Fig. 1 indicated that the amount of removed salts by (T6) were higher than other treatments and control. Treating soil with amendments increased salt removal by 32, 21, 26, $188,270,100$ and $140 \%$ due to T2, T3, T4, T5, T6, T7 and T8, respectively compared with control. Efficiency of treatments was $\mathrm{T}_{6}>\mathrm{T}_{5}>\mathrm{T}_{8}>\mathrm{T}_{7}>\mathrm{T}_{2}>\mathrm{T}_{4}>\mathrm{T}_{3}>\mathrm{T}_{1}$.

Usually, the first period of leaching had the capability to leach the readily soluble salts and mobile ions such as $\mathrm{Cl}^{-}$and $\mathrm{Na}^{+}$, whether the soils were amended or not. After that period, the dissociation of slightly soluble salts $\left(\mathrm{CaSO}_{4}\right.$ and $\left.\mathrm{CaCO}_{3}\right)$ and the exchange between soil solution and exchange complex supply the soil solution with a further amount of soluble ions especially, $\mathrm{Na}^{+}, \mathrm{Ca}^{2+}, \mathrm{SO}_{4}{ }^{\circ}, \mathrm{HCO}_{3}{ }^{-}$and $\mathrm{CO}_{3}{ }^{\circ}$. During the first period of leaching the soluble salts leached from the soil column were mainly $\mathrm{NaCl}$ and $\mathrm{Na}_{2} \mathrm{SO}_{4}$ causing a high $\mathrm{EC}$ values while during the second period the leached salts include in addition to $\mathrm{Na}_{2} \mathrm{SO}_{4}, \mathrm{NaHCO}_{4}$ and finally $\mathrm{Na}_{2} \mathrm{CO}_{3}$. Also, data show that, the decreasing rate of EC values of leached salts was depressed after $4^{\text {th }}$ or $5^{\text {th }}$ leachate in all soil columns. This may be attributed to the favorable effect of amendments on the leacheability through improving the physical properties of the soil.

A study was conducted to investigate the efficiency of leaching process with gypsum, and compost, and their combination on improvement an unproductive salt affected soil by [19]. They found compost with gypsum was more effective than compost alone. Electrical conductivity of percolated water $\left(\mathrm{EC}_{\mathrm{d}}\right)$ values had a sharply decreasing then after the third leaching a slight decreasing was recorded with gypsum treatments. However, the $\mathrm{EC}_{\mathrm{d}}$ values had the same trend, but the slight decreasing was retarded until the $4^{\text {th }}$ leaching with compost treatments. The mean value of $\mathrm{EC}_{\mathrm{d}}$ in leachate was reduced from 32.83 to $4.63 \mathrm{dSm}^{-1}$. This decrease was a function of the leaching numbers of the soil.

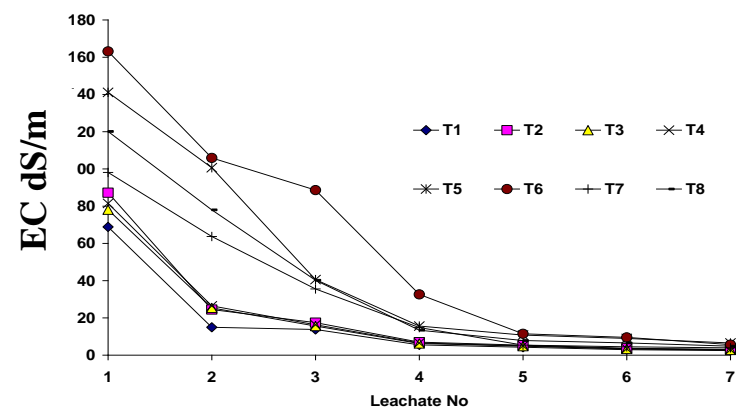

Fig 1. Salt removal as affected by leaching and different amendments

Rice straw compost may increase the moisture holding capacity, maintains sufficient pore spaces to permit good air circulation and drainage of the excessive water and dilution of salt concentrations in the soil solution, ([20], [21], [22], [23] and [24]). [25] pointed out that both organic matter as wheat straw and gypsum ameliorated the black alkaline soil characteristics, but they recommended that addition of decomposed organic matter might be better than wheat straw.

The biological amelioration methods using organic matter have two principal beneficial effects on the saline and alkaline soils reclamation: the improvement of the soil structure and permeability, thus enhancing salt leaching, reducing surface evaporation, and inhibiting salt accumulation in the surface layers; and the release of carbon dioxide during respiration and decomposition ([26]; [27]). 
Although, compost addition retarded the amounts of soluble salts, leaching the soil treated with compost did not create a sodification hazard and ESP obtained at the end of leaching were lower than the control. Similar results were found by [25]. Comparison between the accumulated salts removed by leaching with gypsum and/or compost, revealed that the gypsum with compost was more effective in displacing the TSS. This would be an indirect effect of compost for enhancing good soil physical properties, which lead to better salt leaching processes. [28] suggested that use of about 2-3 times the field capacity of fresh water to remove the excess soluble salts.

\subsection{Soil salinity}

The residual total soluble salts in soil at end of the experiment are shown in Table 4. Leaching was effective in decreasing soil salinity since the EC values ranged between 6.50 to $2.83 \mathrm{dsm}^{-1}$ at end the 7 of leaching of soil in comparison with initial soil $\left(20.34 \mathrm{dSm}^{-1}\right)$. The obtained data showed that different treatments, in the three depths significantly affected electrical conductivity $\left(\mathrm{EC} \mathrm{dSm}^{-1}\right)$. It is clear that the minimum EC values were recorded with application of $\mathrm{T}_{6}$ followed by $\mathrm{T}_{5}$. The $\mathrm{EC}$ values were 6.50 for untreated soil, 4.43, 5.78, 4.58, 3.22, 2.83, 4.31 and $3.93 \mathrm{dsm}^{-1}$ for $\mathrm{T}_{2}, \mathrm{~T}_{3}, \mathrm{~T}_{4}, \mathrm{~T}_{5}, \mathrm{~T}_{6}, \mathrm{~T}_{7}$ and $\mathrm{T}_{8}$, respectively, respectively. Efficiency of treatments was $\mathrm{T}_{6}>\mathrm{T}_{5}>\mathrm{T}_{8}>\mathrm{T}_{7}>\mathrm{T}_{2}>\mathrm{T}_{4}>\mathrm{T}_{3}>\mathrm{T}_{1}$.

Table 4. Effect of different treatments and soil depth on $\mathrm{EC}\left(\mathrm{dSm}^{-1}\right)$

\begin{tabular}{|c|c|c|c|c|}
\hline \multirow{2}{*}{ Treatments } & \multicolumn{3}{|c|}{ Soil depth - cm [AB] } & \multirow{2}{*}{ Mean $[A]$} \\
\hline & $0-10$ & $10-20$ & $20-30$ & \\
\hline $\mathrm{T}_{1}$ & 6.23 & 6.61 & 6.66 & 6.50 \\
\hline $\mathrm{T}_{2}$ & 4.32 & 4.44 & 4.52 & 4.43 \\
\hline $\mathrm{T}_{3}$ & 5.46 & 5.77 & 6.12 & 5.78 \\
\hline $\mathrm{T}_{4}$ & 4.51 & 4.61 & 4.63 & 4.58 \\
\hline $\mathrm{T}_{5}$ & 3.14 & 3.20 & 3.33 & 3.22 \\
\hline $\mathrm{T}_{6}$ & 2.45 & 2.92 & 3.11 & 2.83 \\
\hline $\mathrm{T}_{7}$ & 4.23 & 4.34 & 4.36 & 4.31 \\
\hline $\mathrm{T}_{8}$ & 3.64 & 4.05 & 4.10 & 3.93 \\
\hline Mean $[\mathrm{B}]$ & 4.25 & 4.49 & 4.60 & 4.45 \\
\hline \multirow[t]{2}{*}{$\mathrm{LSD}_{0.05}$} & $\mathrm{~A}$ & $\mathrm{~B}$ & $\mathrm{AB}$ & \\
\hline & 0.09 & 0.05 & 0.15 & \\
\hline
\end{tabular}

For saline or sodic soils, the addition of organic matter can accelerate the leaching of $\mathrm{Na}^{+}$, decrease the ESP and electrical conductivity, and increase water infiltration, water-holding capacity, and aggregate stability ([29] and [30]).

\subsection{Soil reaction}

The soil-pH at end of the experiment is shown in Table 5. The obtained data showed that different treatments significantly affected soil-pH. It is clear that the minimum $\mathrm{pH}$ values were recorded with application of T6 followed by T5. The initial soil-pH (having 8.36) was reduced to 8.14 for untreated soil, 8.06, 8.00, 7.98, 7.86, 7.76, 7.96 and 7.91 for $\mathrm{T}_{2}, \mathrm{~T}_{3}, \mathrm{~T}_{4}, \mathrm{~T}_{5}, \mathrm{~T}_{6}, \mathrm{~T}_{7}$ and $\mathrm{T}_{8}$, respectively, respectively. Efficiency of treatments was $T_{6}>T_{5}>T_{8}>T_{7}>T_{4}>T_{3}>T_{2}>T_{1}$. The decrease in soil $\mathrm{pH}$ due to gypsum application was probably due to combination of more than one factor, mainly the replacement of sodium by calcium and the formation of neutral salts with $\mathrm{SO}_{4}{ }^{2}$. The decrease in soil $\mathrm{pH}$ may have been to a decrease in sodium concentration as a fraction of the cations. This decreasing may be due to removal of exchangeable sodium from the soil column. Moreover, gypsum solubility is also enhanced because of the increased activity coefficient of calcium and sulfate as a result of increased ionic strength of solution and the formation of the sodium sulfate ion pair. Besides, large quantities of $\mathrm{CO}_{2}$ must have been evolved during leaching process, some of which would become soluble in soil solution giving carbonic acids. Concerning compost, the decreases in soil-pH in soil this illustrates the indirect effect of decreased sodium and the direct effect of organic acids, which must have been formed during decomposition of compost.

Applying organic composts to saline sodic soils would help in chelating calcium and decreasing soil $\mathrm{pH}$ leading to an increase in solubility of $\mathrm{CaCO}_{3}[31]$. The organic amendment using rice straw and FYM applied with $25 \%$ GR was similar to $100 \%$ GR in terms of crop [32]. 
Role Of Gypsum And Compost In Reclaiming Saline-Sodic Soils

Table 5. Effect of different treatments and soil depth on soil-pH

\begin{tabular}{c|c|c|c|c}
\hline \multirow{2}{*}{ Treatments } & \multicolumn{3}{|c|}{ Soil depth - cm [AB] } & Mean \\
\cline { 2 - 4 } & $0-10$ & $10-20$ & $20-30$ & {$[\mathrm{~A}]$} \\
\hline $\mathrm{T}_{1}$ & 8.19 & 8.12 & 8.11 & 8.14 \\
$\mathrm{~T}_{2}$ & 8.09 & 8.06 & 8.02 & 8.06 \\
$\mathrm{~T}_{3}$ & 8.01 & 7.99 & 7.99 & 8.00 \\
$\mathrm{~T}_{4}$ & 7.99 & 7.98 & 7.98 & 7.98 \\
$\mathrm{~T}_{5}$ & 7.88 & 7.86 & 7.83 & 7.86 \\
$\mathrm{~T}_{6}$ & 7.81 & 7.79 & 7.74 & 7.78 \\
$\mathrm{~T}_{7}$ & 7.97 & 7.97 & 7.95 & 7.96 \\
$\mathrm{~T}_{8}$ & 7.93 & 7.91 & 7.89 & 7.91 \\
\hline Mean [B] & 7.98 & 7.96 & 7.94 & 7.96 \\
\hline LSD & $\mathrm{A}$ & $\mathrm{B}$ & $\mathrm{AB}$ & \\
\hline
\end{tabular}

Notes: See detail

\subsection{Soil sodicity}

Soil sodicity in terms of ESP of the soil, as well as SAR of the soil past extract, decreased considerably by leaching of the soil (Table 6). Generally, all treatments resulted in a sharp decrease in ESP particularly in the surface layers. This means that by going down in the soil column, the leached solution coming from the upper soil layers caused an increase in the SAR values of the percolating solution, which in turn reduced the replacement of exchangeable sodium with calcium either present in the applied water or solubilized from the added amendments. The ESP at the end of leaching ranged from 8.23 to 4.99 compared with the initial value of 39.55, thus exhibiting a decrease of between 79 to $87 \%$. The SAR takes the same trend as that of the ESP. The SAR value showed decrease which ranged between 85.5 to $90.4 \%$. The $\mathrm{T}_{6}$ showed greater decrease in sodicity than other treatments. Efficiency of treatments was $\mathrm{T}_{6}>\mathrm{T}_{5}>\mathrm{T}_{8}>\mathrm{T}_{7}>\mathrm{T}_{2}>\mathrm{T}_{4}>\mathrm{T}_{3}>\mathrm{T}_{1}$.

Soil organic matter encourages granulation, increases cation exchange capacity (CEC) and is responsible for up to $90 \%$ adsorbing power of the soils. Cations such as $\mathrm{Ca}^{2+}, \mathrm{Mg}^{2+}$ and $\mathrm{K}^{+}$are produced during decomposition [14]. Organic amendments decreased soil sodicity and increased exchangeable $\mathrm{Ca}^{2+}$ and $\mathrm{Mg}^{2+}$ [33].

Table 6. Effect of different treatments and soil depth on soil sodicity

\begin{tabular}{|c|c|c|c|c|c|c|c|c|}
\hline \multirow{3}{*}{ Treatments } & & AR val & & \multirow{3}{*}{$\begin{array}{c}\text { Mean } \\
{[\mathrm{A}]}\end{array}$} & \multicolumn{3}{|c|}{ ESP values } & \multirow{3}{*}{$\begin{array}{c}\text { Mean } \\
{[\mathrm{A}]}\end{array}$} \\
\hline & \multicolumn{3}{|c|}{ Soil depth - cm [AB] } & & \multicolumn{3}{|c|}{ Soil depth - cm [AB] } & \\
\hline & $0-10$ & $10-20$ & $20-30$ & & $0-10$ & $10-20$ & $20-30$ & \\
\hline $\mathrm{T}_{1}$ & 6.25 & 6.44 & 6.46 & 6.38 & 8.03 & 8.32 & 8.35 & 8.23 \\
\hline $\mathrm{T}_{2}$ & 5.20 & 5.27 & 5.32 & 5.27 & 6.48 & 6.59 & 6.66 & 6.57 \\
\hline $\mathrm{T}_{3}$ & 5.85 & 6.01 & 6.19 & 6.02 & 7.44 & 7.69 & 7.95 & 7.69 \\
\hline $\mathrm{T}_{4}$ & 5.32 & 5.33 & 5.39 & 5.35 & 6.65 & 6.67 & 6.75 & 6.69 \\
\hline $\mathrm{T}_{5}$ & 4.44 & 4.48 & 4.57 & 4.49 & 5.34 & 5.40 & 5.53 & 5.42 \\
\hline $\mathrm{T}_{6}$ & 3.92 & 4.28 & 4.41 & 4.20 & 4.56 & 5.10 & 5.30 & 4.99 \\
\hline $\mathrm{T}_{7}$ & 5.15 & 5.22 & 5.23 & 5.20 & 6.40 & 6.50 & 6.51 & 6.47 \\
\hline $\mathrm{T}_{8}$ & 4.78 & 5.04 & 5.07 & 4.96 & 5.84 & 6.23 & 6.28 & 6.12 \\
\hline Mean [B] & 5.11 & 5.26 & 5.33 & 5.23 & 6.34 & 6.56 & 6.67 & 6.52 \\
\hline \multirow[t]{2}{*}{$\mathrm{LSD}_{0.05}$} & $\mathrm{~A}$ & $\mathrm{~B}$ & \multirow{2}{*}{\multicolumn{2}{|c|}{$\mathrm{AB}$}} & $\mathrm{A}$ & $\mathrm{B}$ & \multicolumn{2}{|l|}{$\mathrm{AB}$} \\
\hline & 0.05 & 0.03 & & & 0.07 & 0.05 & 0.13 & \\
\hline
\end{tabular}

Notes: See detail of different treatments (Table 2), A: Treatments effect, B: Soil depth effect and AB: Interaction effect

The leaching alone was reduced the ESP. This attributed to contribute the soil $\mathrm{CaCO}_{3}$ providing an additional source for dissolved $\mathrm{Ca}^{2+}$. The soil $\mathrm{CaCO}_{3}$ was more soluble under saline conditions and effectively participates in the soil actions [34].

Leaching the soil treated with gypsum was more effective in removing the total soluble salts (TSS). Leaching with compost did not create a sodification hazard and ESP obtained values at the end of leaching were lower than the control. As expected the increasing gypsum rates decreased ESP. Moreover, a high degree of soil improvement was realized when leaching began with gypsum + compost and ESP value was decreased [19].

\subsection{Desalinization and desodification leaching curves}

Desalinization leaching curves were constructed to relate the soil salinity after leaching to effective leaching water. The depth of effective leaching water is expressed as ratio to the depth of the soil layer leached Dw/Ds where Dw represents the depth of effective leaching (drainage) water, which can be obtained by adding 
the total depth of percolated water, to the depth of water needed for moistening the soil layer or layers beneath, Ds is the depth of leached soil layer.

Desalinization curves (Fig. 2) show that all treatments reducing soil salinity, with a superiority of $\mathrm{T}_{6}$ in reducing soil salinity. The control was less efficient in reducing soil salinity when comparing with the amendments. Desalinization curves also show that salinity decreased considerably with leaching. Soils amended with all treatments required higher amounts of water to reduce soil salinity compared to those amended with $\mathrm{T}_{6}$. All amendments showed greater Desalinization compared to the control (leaching alone).

Desodification leaching curves were constructed in relation to the residual ESP after leaching expressed as ESP/ESP $\mathrm{o}_{\mathrm{o}}$ to effective leaching water expressed as Dw/Ds. The $\mathrm{ESP}_{\mathrm{o}}$ refers to the initial exchangeable sodium. Desodification leaching curves were illustrated in Fig. 3. Desodification leaching curves takes the same trend as that Desalinization curves where all treatments reducing soil sodicity, with a superiority of $\mathrm{T}_{6}$ in reducing soil salinity and sodicity. As shown in Figs. 2 and 3, $\mathrm{T}_{6}$ was more efficient than other treatments and required substantially lesser amounts of leaching water.

Leaching constant can be calculated by the following equation: $k=(\mathrm{C} / \mathrm{Co})^{*}(\mathrm{Dw} / \mathrm{Ds})$, where $k$ is an empirical coefficient that differs with soil type. The constant $k$ varies with soil type and method of water application. Larger $k$ values indicate more water is required for leaching [35].

The leaching constant $(k)$ was calculated and averaged per each treatment and depth of leached water (Table 7, Figs. 4 and 5). The leaching constants $(k)$ of $\mathrm{T}_{1}, \mathrm{~T}_{2}, \mathrm{~T}_{3}, \mathrm{~T}_{4}, \mathrm{~T}_{5}, \mathrm{~T}_{6}, \mathrm{~T}_{7}$ and $\mathrm{T}_{8}$ averaged $0.67,0.46,0.60$, $0.48,0.34,0.28,0.45$ and 0.40 for desalinization and $0.44,0.35,0.41,0.36,0.29,0.26,0.35$ and 0.33 for desodification, respectively. The smaller values of $k$ in $\mathrm{T}_{6}$ depicted lesser amounts of water required for leaching and reclamation compared to other treatments.

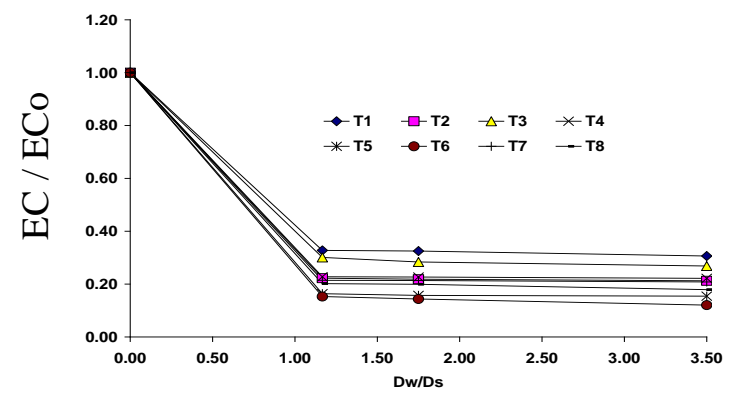

Fig. 2. Desalinization leaching curves, residual $\mathrm{EC}\left(\mathrm{EC} \mathrm{EC} \mathrm{C}_{\mathrm{o}}\right)$ in the soil columns vs. relative depth of effective leaching water (Dw/Ds).

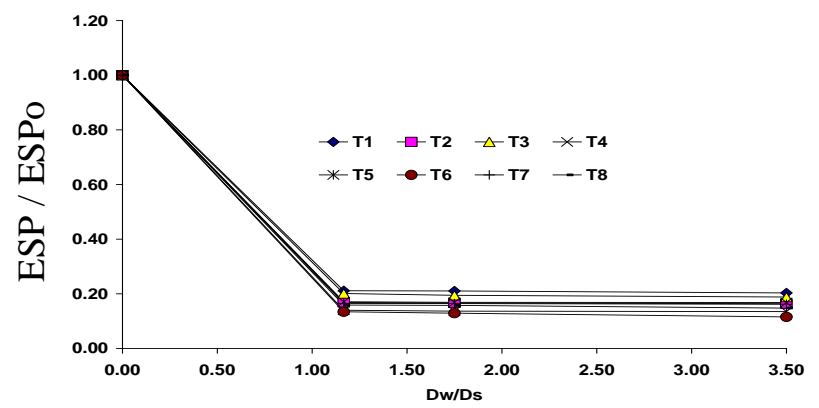

Fig. 3. Desodification leaching curves, residual ESP (ESP/ESPo) in the soil columns vs. relative depth of effective leaching water (Dw/Ds).

Table 7. Leaching constants $(k)$ for soil desalinization and desodification.

\begin{tabular}{|c|c|c|c|c|c|c|c|c|}
\hline \multirow{3}{*}{ Treatments } & \multirow{2}{*}{\multicolumn{3}{|c|}{$\begin{array}{c}\begin{array}{c}\text { Desalinization leaching } \\
\text { constant }(\mathrm{k})\end{array} \\
\text { Dw/Ds } \\
\end{array}$}} & \multirow{3}{*}{ Mean } & \multirow{2}{*}{\multicolumn{3}{|c|}{$\begin{array}{c}\begin{array}{c}\text { Desodification leaching constant } \\
(\mathrm{k})\end{array} \\
\text { Dw/Ds } \\
\end{array}$}} & \multirow{3}{*}{ Mean } \\
\hline & & & & & & & & \\
\hline & 3.5 & 1.75 & 1.17 & & 3.5 & 1.75 & 1.17 & \\
\hline $\mathrm{T}_{1}$ & 1.07 & 0.57 & 0.38 & 0.67 & 0.71 & 0.37 & 0.25 & 0.44 \\
\hline $\mathrm{T}_{2}$ & 0.74 & 0.38 & 0.26 & 0.46 & 0.57 & 0.29 & 0.20 & 0.35 \\
\hline $\mathrm{T}_{3}$ & 0.94 & 0.50 & 0.35 & 0.60 & 0.66 & 0.34 & 0.23 & 0.41 \\
\hline $\mathrm{T}_{4}$ & 0.78 & 0.40 & 0.27 & 0.48 & 0.59 & 0.30 & 0.20 & 0.36 \\
\hline $\mathrm{T}_{5}$ & 0.54 & 0.28 & 0.19 & 0.34 & 0.47 & 0.24 & 0.16 & 0.29 \\
\hline $\mathrm{T}_{6}$ & 0.42 & 0.25 & 0.18 & 0.28 & 0.40 & 0.23 & 0.16 & 0.26 \\
\hline $\mathrm{T}_{7}$ & 0.73 & 0.37 & 0.25 & 0.45 & 0.57 & 0.29 & 0.19 & 0.35 \\
\hline $\mathrm{T}_{8}$ & 0.63 & 0.35 & 0.24 & 0.40 & 0.52 & 0.28 & 0.19 & 0.33 \\
\hline
\end{tabular}




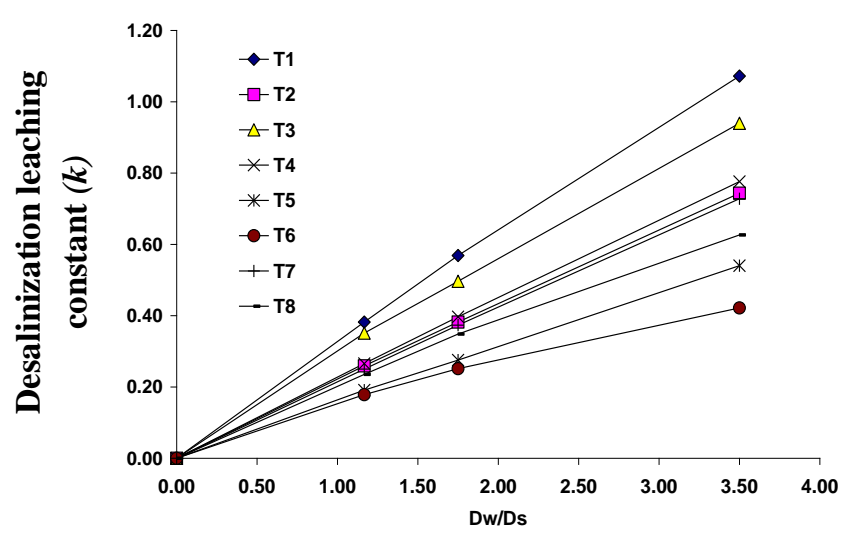

Fig. 4. Leaching constants $(k)$ for soil desalinization vs. Dw/Ds.

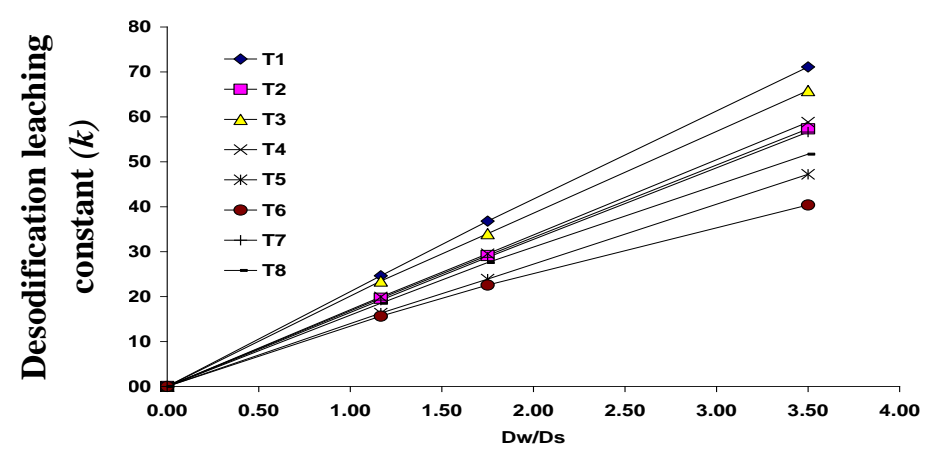

Fig. 5. Leaching constants $(k)$ for soil desodification vs. Dw/Ds.

\section{Conclusion}

A leaching experiment using columns technique was carried out to evaluate the efficiency of gypsum, water hyacinth compost, rice straw compost and their different combinations on reclamation of clay saline-sodic soils. Soils were collected from Sahl El-Hossinia, El-Sharkia Governorate, Egypt. The results showed that, all treatments decreased soil EC, pH, SAR, and ESP compared with control. Application of gypsum combined with water hyacinth compost or rice straw compost enhanced reclamation process and caused more decreases in salinity as well as sodicity. In addition, with increase rate of the gypsum used in reclamation process, more decrease in soil salinity as well as sodicity. Concerning water hyacinth compost and rice straw compost, results showed that, rice straw compost showed a relatively greater effect on reducing EC, $\mathrm{pH}, \mathrm{SAR}$ and ESP compared with water hyacinth compost. The studied treatments could be arranged in the following order, $\mathrm{T}_{6}>\mathrm{T}_{5}>\mathrm{T}_{8}>\mathrm{T}_{7}$ $>\mathrm{T}_{2}>\mathrm{T}_{4}>\mathrm{T}_{3}>\mathrm{T}_{1}$.

\section{Acknowledgments}

The author thanks Professor Dr. Karam Fouad Moussa, professor of Soils, Faculty of agriculture, Zagazig University, Egypt for his valuable guidance through this investigation.

\section{References}

[1] FAO, The use of saline water for crop production. Irrigation and Drainage Paper, 48, 1992, Rome.

[2] E. Amezketa, R. Aragues, and R. Gazol, Efficiency of Sulfuric acid, mined gypsum and two gypsum by-products in Soil crusting prevention and sodic soil reclamation. Agron. J., 97,2005, 983-989.

[3] V. N. L. Wong, R. C. Dalal, and R. S. B. Greene, Carbon dynamics of sodic and saline soils following gypsum and organic material additions: a laboratory incubation. Applied Soil Ecology, 41, 2009, 29-40.

[4] M. A. Hamza and W. K. Anderson, Responses of soil properties and grain yields to deep ripping and gypsum application in a compacted loamy sand soil contrasted with a sandy clay loam soil in Western Australia. Australian Journal of Agricultural Research, 54, 2003, 273-282.

[5] W. H. Vance, J. M. Tisdell and B. M. McKenzie, Residual effects of surface application of organic matter and calcium salts on the subsoil of a red brown earth. Australian Journal of Experimental Agriculture, 38, 1998, 595-600.

[6 ] M. Iranzo, J. V. Canizares, L. R. Perez, I. S. Pardo, S. Mormeneo and R. Boluda, Characteristics of rice straw and sewage sludge as composting materials in Valencia (Spain). Bioresource Technology, 95, 2004, 107-112

[7] E. L. Ndiaye, J. M. Sandeno, D. Mcgrath, and R. P. Dick, Integrative biological indicators for detecting change in soil quality. American Journal of Alternative Agriculture, 15, 2000, 26-36.

[8] E. Madejon, R. Lopez, J. M. Murillo and F. Cabrera, Agricultural use of three (sugar beet) vinasse composts: Effect on crops and chemical properties of Cambisol soil in the Gauadalquivir river valley (SW Spain). Agriculture, Ecosystems \& Environment, 84, 2001, 55-65. 
[9] S. Melero, E. Madejón, J. F. Herencial and J. C. Ruiz, Biochemical properties of two different textured soils (loam and clay) after the addition of two different composts during conversion to organic farming. Spanish Journal of Agricultural Research, 5(4), 2007, 593-604.

[10] R. G. Courtney and G. J. Mullen, Soil quality and barley growth as influenced by the land application of two compost types. Bioresource Technology, 99, 2008, 2913-2918.

[11] C. Chitravadivu , V. Balakrishnan, J. Manikandan, T. Elavazhagan and S. Jayakumar, Application of food waste compost on soil microbial population in groundnut cultivated soil, Middle East Journal of Scientific Research, 4(2), 2009 90-93.

[12] N. Hussain, G. Hassan, M. Arshadullah and F. Mujeeb, Evaluation of amendments for the improvement of physical properties of sodic soil. International Journal of Agriculture and Biology. 3, 2001, 319-322.

[13] N. Hussain, G. Hassan, A. Ghafoor and G. Sarwar, Proc. Sixth Int. Micro Irrigation Cong. Florida, 1998 :293-300.

[14] N.C. Brady and R.R. Weil, The nature and properties of soils. 13thEdition. Macmillan Publishing Company, New York,. 2005, 279313.

[15] USDA, Diagnosis and improvement of saline and alkali soils. (Agriculture Hand Book No. 60 US Gov. Printing Office, Washington, 1954).

[16] R. C. Reeve, The relation of salinity to irrigation and drainage requirement. $3^{\text {rd }}$ Cong. on Irrigation and Drainage. Tran. 5, 1975, 157-187.

[17] D. F. Russell, MSTAT-C v.2.1 (computer based data analysis software). Crop and Soil Sci. Department, Michigan State University, USA, 1994.

[18] H. F. E. El-Missiry, Productivity of some salt-affected soils as influenced by chemical amendments and organic materials. Ph.D. Thesis, Fac. of Agric. Mashtohor Zagazig Univ. (Benha Branch), Egypt, 2001.

[19] A. EL-Ashtar and F. ElEtreiby. Influence of leaching with gypsum and compost of rice straw on improvement of Salt Affected Soil and Rice Growth. Alex. Sci. Exch. J. 27(2), 2006, 214-221.

[20] H. Luken. Saline soils under dry land agriculture in southeastern Saskatchewan (Canada)and possibilities part III: Influence of organic applications on soil salinity and crop yields. Plant and soil, 17(1), 1962, 49- 67.

[21] B.S. Puttaswamygowda and P.F. Pratt. Effects of straw, calcium chloride, and submergence on a sodic soil. Soil Sci.Soc. Amer. Proc.37, 1973, 208-212.

[22] R.K. Gupta, D.K. Bhumbla, and I.P. Abrol. Effect of sodicity, pH, organic matter, and calcium carbonate on the dispersion behavior of soils. Soil Sci., 137, 1984, 245-251.

[23] F. El Etreiby. Maintien et amélioration de la fertilité des sols. Les amendements. Quatrieme seminaire de formation. Project d'appui au service maraicher et fruitier. ISABU, Burundi. 1992.

[24] N. EL Etreiby, T. S. Shehata, and J.J. Scalbroeck. The influence of composting on the fertilizing value of rice straw and the evaluation of these composts on soil properties and rice productivity. Alex. Sci.Exch., 17 (2), 1996, $41-153$.

[25] A.H.I. Moustafa and A.I. Shabassy. The effect of gypsum and gypsum plus organic matter on the chemical and physical properties of black alkaline soils in Egypt. Agric. Ext. Dept., Min. Agric., Egypt. Tech. Bull. 286, 1959, 1-47.

[26] Z. Q. Wang and L.Q. Li. Salinization in China and its Prevention, Studies on the Prevention of Land Degra $\neg$ dation in China. Agricultural Science and Technology Press of China, Bejing. 1990.

[27] S. Matsumoto, Q. Zhao, J. Yang, S. Zhu and L. Li. Salinisation and its environmental hazard on sustainable agriculture in East Asiaand its neighbouring regions. In: 15th Congr. Soil Sciences, Mexico, 1994, 236-255.

[28] V. A. Kovda. Principles of theory and practices of reclamation and utilization of saline soils in the arid zones. Proc. Tehran. Symposium." Salinity Problems in arid zones". UNESCO Pub. 1961, 201-231.

[29] A., Lax, E. Diaz, V. Castillo and J. Albaladejo. Reclamation of physical and chemical properties of a salinized soil by organic amendment. Arid Soil Research and Rehabilitation, 8, 1994, 9-17.

[30] M. Qadir, S. Schubert, A. Ghafoor and G. Murtaza. Amelioration strategies for sodic soils: A review. Land Degradation and Development, 12, 2001, 357-386.

[31] Y. Avinelech, M. Kochba, Y. Yotal, and D. Shkedi, On the use of municipal solid waste compost for the reclamation of saline and alkaline soils. Transaction $14^{\text {th }}$ Inter. Cong. Of Soil Sci. Kyoto, Japan, 6, 1990, 186-191.

[32] Z. Anwar, M. Fakhar, S. Ghulam, N. M. Hassan, and G. Hassan, Agromelioration of saline sodic soils. Online J. of Biological Sciences, 3(3), 2003, 329-334.

[33] S. Anand, Effect of organic amendments on the nutrition and yield of wetland and sodic soil reclamation. J. Indian Soc. Soil Sci. 40(4), 1992, 816-822.

[34] A. M. Balba. Effect of waters with different sodium and carbonate concentration on the soil chemical properties and the growth and composition of plant. J. Soil Sci. U.A.R. 2, 1963, 85-97.

[35] G. J. Hoffman, Guidelines for the reclamation of salt affected soils. Applied Agric. Res. 1(2), 1986, 65-72. 